\title{
HGS seeks exclusive option on all patents using its cDNA sequences
}

London. In a move that will have a wide impact on the molecular genetics community, the gene-sequencing company Human Genome Sciences Inc. (HGS) has released details of the terms that university-based scientists will have to accept if they wish to work with sequences produced by HGS's Institute of Genomic Research (TIGR).

If - as expected - the terms are endorsed by a number of major research institutions, the move will clear the way for the publication of information on almost 150,000 cDNA sequences compiled by TIGR, headed by Craig Venter, formerly of the National Institutes of Health.

But the fact that the terms provide HGS with the opportunity to retain control over the commercial applications of knowledge derived from the sequences, and in particular the discovery of any genes arising directly from this knowledge, means that controversy over the company's actions is unlikely to disappear.

The publication of the agreement follows an announcement on Monday by HGS and SmithKline Beecham, which last year took a major equity stake in HGS, that they are planning to open up shortly to the academic community a Human cDNA Database containing all cDNA sequences compiled by TIGR at its sequencing laboratory in Gaithersburg, Maryland.

It also follows last week's announcement by rival pharmaceutical company Merck Sharpe \& Dohme that, in apparent protest at SmithKline's efforts to 'corner' the commercial use of the human genome, it is financing a separate sequencing project at the University of Washington, St Louis, whose results will be placed unrestricted in the public domain (see Nature 371, 365; 1994).

The main condition of access to the TIGR database is that the institution for which an investigator works must sign an 'option agreement' with HGS, under which HGS will have an exclusive option on any patents arising from research using the database sequences.

As part of a separate 'access agreement', an investigator must agree that all scientific papers arising from research using the TIGR sequences will be submitted to HGS at least 30 days before publication, giving the company time to decide whether a patent application should be filed. (HGS will have the right to demand a further 30 days delay to pursue a patent application.)

If it is interested in pursuing the discovery commercially, the company will have six months in which to negotiate an accept- able deal with the university. At the end of six months, if HGS decides not to pursue the negotiations further, then the university (which will own the patent rights to the invention) will be free to enter into negotiations with other companies interested in taking out a licence on the patent.

According to George Poste, research director of SmithKline, the terms of the agreement are little different from those that any commercial sponsor would attach to its support for a university-based group of researchers. He argues that free access to the cDNA database should be considered a com-

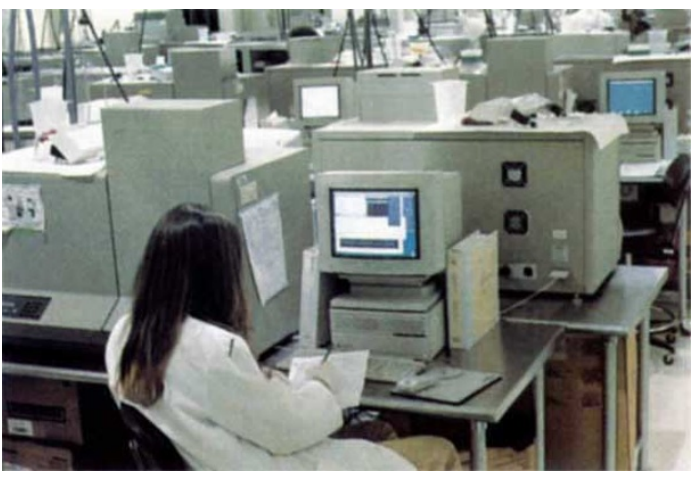

The Institute for Genomic Research has already sequenced over 100 million nucleotides.

parable form of support for university scientists to a grant which they might receive directly from a pharmaceutical company.

But SmithKline's conditions are unlikely to please other companies, who will be required to enter into commercial agreements with HGS if they wish to use the TIGR sequences in their own development work. "Commercial organizations are welcome to approach us, and we would be happy to discuss terms for collaboration," says Poste.

SmithKline executives dismiss Merck's move to establish a separate 'public domain' sequencing operation on the grounds that HGS already has a substantial head start in compiling cDNA sequences through the efforts of TIGR. "We have always realized the importance of moving rapidly, and it seems that others are now planning to start on a process which we have almost completed," says William Haseltine, the chief executive officer of HGS

Both Poste and Haseltine defend the relatively aggressive stance that HGS has taken in driving hard bargains with commercial competitors who would like access to the TIGR data. "The essence of industry is competition," says Poste, who has described genes as a form of "currency" to be used in negotiations with potential partners. "Whether this is expressed through actions to boost your own competitive position, or by attempts to reduce another company's ability to compete - that has long been the cut and thrust of industry."

At the same time, the agreement could cause difficulties for academic geneticists who hold equity stakes in, or act as directors of, small gene-hunting companies. If they wish to use TIGR data, an agreement giving HGS a first option on the use of patents arising from the data could come into conflict with a legal commitment to provide their company with all information relevant to its interests.

"For academics with company ties which go beyond consultancy arrangements or research grants, and may include a legally binding obligation [to a company], it is their own ethics that will determine what they do with the data," says Poste. "But I hope that they would recognize a potential conflict of interest."

The agreement released on Monday is the latest product of prolonged effort by HGS to develop terms for access to and the use of TIGR data. Earlier versions of so-called "material transfer agreements" provoked widespread protests in the academic community, partly as a result of complaints from university patent lawyers who felt that HGS was restricting the ability of their institutions to negotiate separate deals with other commercial sponsors of research.

Overall, the dispute has provoked widespread debate over whether the generation of a 'transcript map', involving the mapping of cDNA sequences on to a physical map of the genome, should be carried out in the public or the private domain.

HGS and SmithKline officials remain unapologetic about the stance that they have taken. "We have committed more than $\$ 100$ million to Craig Venter's work at TIGR, as well as an extra $\$ 8.5$ million in making the database available to the academic community, and feel that we have a reasonable right to profit from any results that emerge from something that we have made an investment in," says Poste.

But Merck, backed by a number of other pharmaceutical companies who fear that HGS could exert excessive control over the commercial applications of cDNA sequences - and claim that this could reflect back negatively on the academic community plans to maintain its strategy. "The more genomic information is available for researchers to use on an unrestricted basis, the more likely that we will see important discoveries and progress in our knowledge of the human genome," says Merck spokesman Jeff Sturchio.

David Dickson 